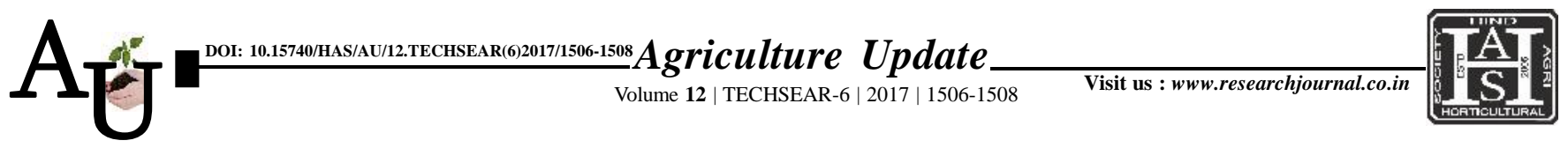

\title{
Reserct Article: Influence of in-situ moisture conservation practices on productivity of rainfed groundnut
}

Article Chronicle : Received :

17.07.2017;

Accepted :

01.08.2017
KEY Words:

Broad bed, Furrow system, Groundnut, Rainfed, Yield attributes, Yield
Author for correspondence :

\section{G. RAJITHA}

Department of Agronomy, S.V. Agricultural College, TIRUPAT (A.P.) INDIA

Email: rajirajitha41@ gmail.com

See end of the article for authors' affiliations

\section{G. RAJITHA, G. PRABHAKARA REDDY, A. MUNEENDRA BBAU AND P. SUDHAKAR}

SUMMARY : A field experiment was conducted during Kharif, 2016-17 at Agricultural College Farm, Tirupati to study the effects of in-situ moisture conservation techniques on the productivity of rainfed groundnut (Arachis hypogaea L.). Broad bed and furrows were effective in conserving the soil moisture leading to improvement in yield attributes and hence, the pod and haulm yields of groundnut. The highest pod yield of $2056 \mathrm{~kg} \mathrm{ha}^{-1}$ was recorded with broad bed and furrows.

How to cite this article : Rajitha, G., Reddy, G. Prabhakara, Bbau, A. Muneendra and Sudhakar, P. (2017). Influence of in-situ moisture conservation practices on productivity of rainfed groundnut. Agric. Update, 12(TECHSEAR-6) : 1506-1508; DOI: 10.15740/HAS/AU/12.TECHSEAR(6)2017/1506-1508. 